\title{
DO LUGAR DISCURSIVO AO EFEITO-LEITOR: A MOVIMENTAÇÃO DO SUJEITO NO DISCURSO EM BLOGS DE DIVULGAÇÃo CIENTÍFICA
}

\author{
Autora: Gerenice Ribeiro de Oliveira Cortes \\ Ano de defesa: 2015 \\ Orientadora: Evandra Grigoletto \\ Instituição: Universidade Federal de Pernambuco
}

A pesquisa, que deu origem à Tese, analisa o funcionamento do efeito-leitor no discurso de divulgação científica (DDC), inscrito nos blogs do ScienceBlogs Brasil (Sb.br), a partir dos aportes teóricos da Análise de Discurso (AD) de filiação pecheuxtiana, em diálogo com alguns estudos da comunicação e das ciências sociais. Nesse estudo, o hipertexto não é considerado como mero suporte digital, pois é constituído de recortes da memória e tecido por muitas camadas, por isso pode ser concebido como um grande palimpsexto eletrônico. Da mesma forma, o blog é tomado com um objeto discursivo, que também afeta o DDC. As análises mostram o funcionamento de dois efeitos-leitores dominantes nesse discurso: o efeitoleitor analfabeto-científico e o especialista, respectivamente, afetados pelo imaginário do leitor leigo e do leitor cientista. Tais efeitos, por sua vez, também determinam o imaginário de ciência divulgada nos blogs. O efeitoleitor funciona no DDC do Sb.br intrincadamente ao lugar discursivo e à posição-sujeito ocupada, sendo que, nessa trama, uma posição-sujeito também é projetada ao leitor. Diante do efeito-leitor analfabeto-científico, o sujeito do discurso, isto é, o sujeito divulgador, se inscreve no lugar discursivo de porta-voz para interpretar a ciência e ocupa distintas posiçóes-sujeito, das quais se destaca a de alfabetizador de ciência. Nesse discurso, posiçôessujeito também são projetadas ao leitor leigo, em especial, a de consumidor de informaçóes científicas. Já, diante do efeito-leitor especialista, o sujeito divulgador se inscreve no lugar discursivo de pesquisador e projeta - ao leitor cientista - a mesma posiçấo-sujeito que ele ocupa: a de interlocutor de ciência. $\mathrm{Na}$ interlocução discursiva instituída na seção de comentários, instaura-se uma tensão entre o efeito-leitor projetado no discurso e o sujeito leitor, enquanto que o sujeito divulgador, pelo viés do lugar discursivo de moderador, institui a interdição e o controle da leitura. Todavia, o leitor se inscreve no lugar discursivo de autor e não deixa de produzir sentidos, pois 
não se identifica com os saberes da formação discursiva (FD) da divulgação científica, ocupando distintas posiçóes-sujeito que se confrontam com o efeito-leitor analfabeto-científico e com a posiçáo-sujeito que lhe é projetada. Portanto, pode ocorrer a falha no ritual através da passagem da interação, que é imposta, para a interlocução discursiva. 